\title{
Incidence of Duchenne muscular dystrophy in New South Wales and the Australian Capital Territory
}

\author{
JUDITH COWAN, JOHN MACDESSI, ALAN STARK, AND \\ GRAEME MORGAN
}

From the Division of Paediatric Medicine and Genetics, Prince of Wales Children's Hospital, Randwick, Australia, and the School of Community Medicine, University of New South Wales, Kensington, Australia

SUMMARY A survey was conducted during 1977 to 1978 to determine the incidence of Duchenne muscular dystrophy in New South Wales and the Australian Capital Territory. Ninety-nine cases born between 1960 and 1971 were ascertained, representing an incidence rate of 18.6 per 100000 liveborn males. Over $60 \%$ of the ascertained males were isolated cases, and only $7 \%$ of affected males had an affected male relative in a previous generation in the female line. Categorisation of ascertained cases as either 'theoretically preventable' or not shows that genetic counselling alone in the present circumstances is insufficient to reduce the incidence rate significantly.

Duchenne muscular dystrophy is a lethal $\mathrm{X}$ linked recessive disorder. From the time of diagnosis, usually between the ages of 3 and 7 , boys affected by the disease follow a course of progressive muscle weakness and wastage until death in their late teens or twenties. Affected males will almost certainly come to the attention of a medical practitioner at some stage of the disease because of its severity. Consequently, ascertainment of affected cases is very high.

Within New South Wales and the Australian Capital Territory, the existence of the Muscle Diseases Clinic at the Prince of Wales Children's Hospital is well known, and most cases of Duchenne muscular dystrophy are referred there. Since its establishment in 1965, the Clinic has facilitated much of the treatment and genetic counselling relating to Duchenne muscular dystrophy in this region. More than a decade later, it was felt that sufficient reliable data had been accumulated to justify a study of the incidence of Duchenne muscular dystrophy in New South Wales and the Australian Capital Territory.

\section{Collection of data}

The survey was conducted during 1977 to 1978 . The years between 1960 and 1971 inclusive were chosen as the most suitable period over which to determine the incidence rate. Cases born before 1960 would Received for publication 10 October 1979 have been increasingly difficult to follow up. In some instances, uncertain diagnosis for cases assessed elsewhere would have compounded these problems. At the same time, it would be unreasonable to expect all cases born after 1971 to have been diagnosed by 1978 .

It was expected from the outset that most cases would be ascertained from the files of the Muscle Diseases Clinic. Records of other cases were sought from paediatric clinics in Sydney and the other major cities in New South Wales and the Australian Capital Territory (Newcastle, Wollongong, and Canberra), as well as from the New South Wales Society for Crippled Children.

As it turned out, all but five of the 99 cases born between 1960 and 1971 were assessed or received treatment at some stage at the Clinic.

The dates and places of birth of all cases were checked carefully. Since there has been a large influx of immigrants to Australia in the post-war period, it was important to exclude any cases born outside the specified area from the calculations.

\section{Results}

\section{INCIDENCE RATES}

Conventionally, the rate of incidence of Duchenne muscular dystrophy is measured by the ratio of affected males born within a given period and geographical area to the total number of male 
livebirths in the same period and place. GardnerMedwin $^{1}$ suggested that it was more appropriate to express the incidence of a disorder not diagnosed at birth in terms of the liveborn children surviving to the age of ascertainment. Accordingly, he proposed that the incidence of Duchenne muscular dystrophy should be calculated in terms of the number of liveborn males surviving to 5 years of age.

This survey ascertained 99 cases of Duchenne muscular dystrophy born in New South Wales and the Australian Capital Territory between 1960 and 1971. The rate of incidence over this period was 18.60 per 100000 male livebirths, or 19.13 per 100000 liveborn males surviving to 5 years of age. Thus, one per 5377 liveborn males, or one per 5226 liveborn males surviving to 5 years, born between 1960 and 1971, had Duchenne muscular dystrophy.

The annual incidence rates expressed in terms of male livebirths (table 1) show some fluctuation. They vary from $13.9 \times 10^{-5}$ in 1968 to $24.0 \times 10^{-5}$

TABLE 1 Incidence of Duchenne muscular dystrophy in New South Wales and the Australian Capital Territory, 1960-1971

\begin{tabular}{lcll}
\hline $\begin{array}{l}\text { Year of } \\
\text { birth }\end{array}$ & $\begin{array}{l}\text { DMD } \\
\text { cases }\end{array}$ & $\begin{array}{l}\text { Male livebirths } \\
\text { NSW and ACT }\end{array}$ & $\begin{array}{l}\text { Incidence per } \\
\text { 100 000 MLBs }\end{array}$ \\
\hline 1960 & 9 & 43068 & $20 \cdot 9$ \\
1961 & 9 & 45091 & $20 \cdot 0$ \\
1962 & 9 & 44929 & $20 \cdot 0$ \\
1963 & 7 & 44070 & $15 \cdot 9$ \\
1964 & 8 & 42448 & $18 \cdot 8$ \\
1965 & 7 & 41334 & $16 \cdot 9$ \\
1966 & 6 & 41324 & $14 \cdot 5$ \\
1967 & 10 & 41694 & $24 \cdot 0$ \\
1968 & 6 & 43249 & $13 \cdot 9$ \\
1969 & 11 & 45745 & $24 \cdot 0$ \\
1970 & 8 & 47011 & $17 \cdot 0$ \\
1971 & 9 & 52339 & $17 \cdot 2$ \\
Total & 99 & 532302 & $18 \cdot 6$ \\
\hline
\end{tabular}

in 1967 and 1969. However, a simple $\chi^{2}$ test show: no significant change in these annual rates over the period 1960 to $1971\left(\chi_{11}^{2}=2 \cdot 84, p>0 \cdot 05\right)$.

FAMILIAL AND ISOLATED CASES

The 99 cases were divided into familial and isolated cases (table 2). In order to avoid any confusion about the meaning of the term 'sporadic case', an affected male proband who was the only affected member of his family was designated an 'isolated case'. The familial cases were subdivided further according t $\dot{\sigma}$ their relationship to other affected male relatives (table 2).

Of all cases born between 1960 and 1971, in clusive, $63(64 \%)$ were isolated cases and $34(34 \%$ 文 were familial cases. The two boys who could not bo categorised as either isolated or familial cases had been adopted before the diagnosis was made Efforts to obtain a family history for these two cases have been unsuccessful so far.

There were only seven cases with an affected male relative in a previous generation in the female line The youngest of these seven boys was born in 1967? In addition to these cases, there is one other with $\overrightarrow{a b}$ positive family history. In this 'familial' case Duchenne muscular dystrophy originated twice ip the one family. The affected cousins are relate through their respective fathers (fig).

Using realistic definitions it is possible to divid the affected males into those who were "theoreticallo preventable' by genetic counselling, and those who were not. Affected males with at least one affecte $\bar{\phi}$ male relative in a previous generation in the female line must be classified as 'theoretically preventable Similarly, the birth of any affected brother at least 6 years after the index case in a given sibship should be regarded as preventable.

TABLE 2 Familial and isolated cases of Duchenne muscular dystrophy born in New South Wales and the Australian Capital Territory, 1960-1971

\begin{tabular}{|c|c|c|c|c|c|c|c|}
\hline \multirow{2}{*}{$\begin{array}{l}\text { Year } \\
\text { of } \\
\text { birth }\end{array}$} & \multirow{2}{*}{$\begin{array}{l}\text { Isolated } \\
\text { cases }\end{array}$} & \multicolumn{5}{|c|}{ Affected familial cases } & \multirow{2}{*}{$\begin{array}{l}\text { Not } \\
\text { known }\end{array}$} \\
\hline & & Brother(s) & Uncle & $\begin{array}{l}\text { First cousin } \\
\text { once removed }\end{array}$ & $\begin{array}{l}\text { Great- } \\
\text { uncle }\end{array}$ & $\begin{array}{l}\text { Brother } \\
\text { and uncle }\end{array}$ & \\
\hline $\begin{array}{l}1960 \\
1961 \\
1962 \\
1963 \\
1964 \\
1965 \\
1966 \\
1967 \\
1968 \\
1969 \\
1970 \\
1971\end{array}$ & $\begin{array}{l}5 \\
5 \\
4 \\
5 \\
3 \\
3 \\
5 \\
5 \\
9 \\
6 \\
6\end{array}$ & $\begin{array}{l}3 \\
4 \\
3 \\
1 \\
4 \\
2 \\
4 \\
1 \\
2 \\
1 \\
2\end{array}$ & $\begin{array}{l}1 \\
1\end{array}$ & 1 & 1 & 1 & $\begin{array}{l}1 \\
1\end{array}$ \\
\hline Total & 63 & 27 & 4 & 1 & 1 & 1 & 2 \\
\hline
\end{tabular}




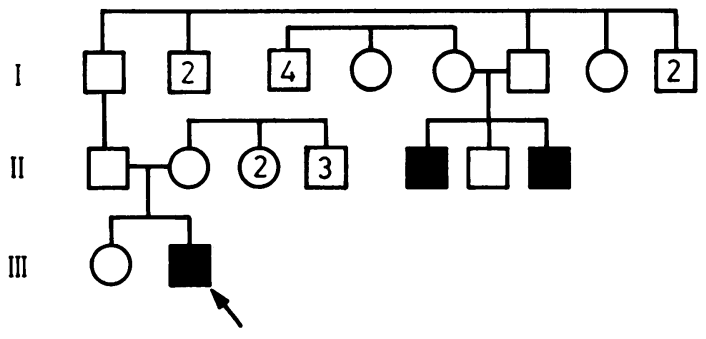

FIGURE Pedigree of an isolated case of Duchenne muscular dystrophy born in 1966 with affected male relatives in the male line.

The incidence of such cases over the period 1960 to 1971 (table 3) is quite small. Only 14 cases can be classified thus, and there is a noticeable downward trend in the incidence rates grouped into four 3year periods. However, the grouping of these results into two 6-year periods shows that this trend is not significant $\left(\chi_{1}^{2}=1 \cdot 31, \mathrm{p}>0 \cdot 05\right)$.

\section{Discussion}

In terms of the number of male livebirths covered, this survey of the incidence of Duchenne muscular dystrophy in New South Wales and the Australian Capital Territory is the largest study recorded (table 4, 5). A high level of ascertainment was expected for a number of reasons. New South Wales and the Australian Capital Territory are highly urbanised. At the Census of 30 June 1976, $80 \%$ (3 $909100 / 4907500$ ) of the population in New South Wales lived in urban areas with a population greater than $25000 .{ }^{17}$ There is a centralised and widely known system of treatment and counselling available for Duchenne muscular dystrophy through the Muscle Diseases Clinic. In addition, most children with disabilities are registered with the New South Wales Society for Crippled Children (NSWSCC). The NSWSCC operates specialised schools for handicapped children and offers assistance with the provision of specialised equipment

TABLE 3 Incidence of preventable cases of Duchenne muscular dystrophy in New South Wales and the Australian Capital Territory, 1960-1971

\begin{tabular}{|c|c|c|c|c|c|}
\hline \multirow[t]{2}{*}{ Period } & \multicolumn{2}{|c|}{$D M D$ cases } & \multirow{2}{*}{$\begin{array}{l}\text { Male livebirths } \\
\text { NSW and } A C T\end{array}$} & \multicolumn{2}{|c|}{ Incidence per $10^{5} \mathrm{MLBS}$} \\
\hline & Total & Preventable & & Total & Preventable \\
\hline $\begin{array}{l}1960-1962 \\
1963-1965 \\
1966-1968 \\
1969-1971\end{array}$ & $\begin{array}{l}27 \\
22 \\
22 \\
28\end{array}$ & $\begin{array}{l}4 \\
5 \\
3 \\
2\end{array}$ & $\begin{array}{l}133088 \\
127852 \\
126267 \\
145095\end{array}$ & $\begin{array}{l}20 \cdot 3 \\
17 \cdot 2 \\
17 \cdot 4 \\
19 \cdot 3\end{array}$ & $\begin{array}{l}3 \cdot 0 \\
3 \cdot 9 \\
2 \cdot 4 \\
1 \cdot 4\end{array}$ \\
\hline Total & 99 & 14 & 532302 & $18 \cdot 6$ & $2 \cdot 6$ \\
\hline
\end{tabular}

TABLE 4 Studies of the incidence of Duchenne muscular dystrophy in Australia

\begin{tabular}{|c|c|c|c|c|}
\hline Region and dates of study & DMD cases & Male livebirths & Incidence per $100000 \mathrm{MLBs}$ & Source \\
\hline $\begin{array}{l}\text { Western Australia 1950-1969 } \\
\text { Victoria 1957-1963 } \\
\text { NSW and ACT 1960-1971 } \\
\text { Queensland 1962-1971 }\end{array}$ & $\begin{array}{l}35 \\
49 \\
99 \\
30\end{array}$ & $\begin{array}{l}173126 \\
223330 \\
532302 \\
182980\end{array}$ & $\begin{array}{l}20 \cdot 2 \\
21 \cdot 9 \\
18 \cdot 6 \\
16 \cdot 4\end{array}$ & $\begin{array}{l}\text { Kakulas and Hurse }{ }^{2} \\
\text { Lawrence } \text { et } \text { al }^{3} \\
\text { Present study } \\
\text { Adkins }{\text { et } \text { al }^{4}}^{4}\end{array}$ \\
\hline
\end{tabular}

TABLE 5 Published studies of the incidence of Duchenne muscular dystrophy outside Australia

\begin{tabular}{|c|c|c|c|c|}
\hline Region and dates of study & DMD cases & Male livebirths & Incidence per $100000 \mathrm{MLBs}$ & Source \\
\hline $\begin{array}{l}\text { South Baden 1918-1932 } \\
\text { Utah 1931-1940 } \\
\text { Leeds 1939-1949 } \\
\text { Bern, Switzerland 1939-1954 } \\
\text { Northumberland 1940-1949 } \\
\text { Northern Ireland 1942-1951 } \\
\text { Fukuska City, Japan 1949-1958 } \\
\text { Newcastle, UK 1952-1960 } \\
\text { Warsaw 1953-1960 } \\
\text { SE Scotland 1953-1968 } \\
\text { Venetia, Italy 1956-1968 }\end{array}$ & $\begin{array}{r}18 \\
18 \\
7 \\
26 \\
18 \\
28 \\
9 \\
77 \\
46 \\
47 \\
66\end{array}$ & $\begin{array}{r}125000 \\
63000 \\
46210 \\
119395 \\
138403 \\
153692 \\
46465 \\
261925 \\
328110 \\
117413 \\
234369\end{array}$ & $\begin{array}{l}14 \cdot 4 \\
26 \cdot 6 \\
15 \cdot 1 \\
21 \cdot 8 \\
13 \cdot 0 \\
18 \cdot 2 \\
19 \cdot 4 \\
29 \cdot 4 \\
14 \cdot 0 \\
26 \cdot 5 \\
28 \cdot 2\end{array}$ & $\begin{array}{l}\text { Becker and Lenz } 6 \\
\text { Stephens and Tyler } 7 \\
\text { Blyth and Pugh } 8 \\
\text { Moser et al9 } \\
\text { Walton }{ }^{10} \\
\text { Stevenson } 1112 \\
\text { Kuroiwa and Miyazaki } 13 \\
\text { Gardner-Medwin }{ }^{1 *} \\
\text { Prot } 14 \\
\text { Brooks and Emery } 15 \\
\text { Danieli } \text { et al } 16\end{array}$ \\
\hline
\end{tabular}

*Gardner-Medwin presented the incidence rate in terms of MLBs surviving to 5 years. His figures have been adjusted here to be directly comparable with other surveys. 
such as wheelchairs. Most disabled children, apart from some catered for by other specific organisations, are registered with the society by their doctors. Consequently, the incidence rate of $18.6 \times 10^{-5}$ should be quite close to the true rate.

The incidence rates calculated for four Australian States and one Territory (table 4) agree quite well with one another and suggest that the incidence of Duchenne muscular dystrophy in Australia is somewhat lower than reliable studies published recently for other regions. ${ }^{115} 16$

Among the lower incidence rates found in other studies shown in table 5 , some can be attributed to under-ascertainment of affected cases. Analysis of the data from the study of Walton ${ }^{10}$ showed a deficiency of isolated cases. ${ }^{18}$ Prot $^{14}$ acknowledged 'imperfect' ascertainment in her survey. The study of cases in South Baden ${ }^{6} 6$ was made over 20 years after the period of births covered, so it is not unreasonable to expect incomplete ascertainment in this study. Finally, random fluctuation alone could account for the low incidence reported in Leeds. ${ }^{8}$ The male births covered for the 11 years in Leeds approximate those for one year in New South Wales and the Australian Capital Territory, and as this latter study has found, the annual incidence rates ranged from $13.9 \times 10^{-5}$ to $24.0 \times 10^{-5}$ (table 1).

The overall proportion of isolated cases found in this survey was $0 \cdot 64$. This is a higher level than that of 0.56 determined by Gardner-Medwin, ${ }^{1}$ despite the higher incidence rate recorded in the Newcastleupon-Tyne survey. The contribution of underascertainment to a low incidence rate would be reflected by a deficiency of isolated cases, as shown, for example, in the Northumberland and Durham study. ${ }^{18}$

A breakdown of the proportion of isolated cases for the four consecutive 3-year periods (table 6), shows that in the last period (1969 to 1971) this proportion had reached the high level of 0.81 , suggesting that genetic counselling has had some effect in reducing the number of familial cases born more recently.

However, during the period that the proportion

TABLE 6 Proportions of isolated cases of Duchenne muscular dystrophy in New South Wales and the Australian Capital Territory, 1960-1971

\begin{tabular}{llll}
\hline Period & $\begin{array}{l}\text { Isolated } \\
\text { cases }\end{array}$ & $\begin{array}{l}\text { Familial } \\
\text { cases }\end{array}$ & $\begin{array}{l}\text { Proportion of } \\
\text { isolated cases }\end{array}$ \\
\hline $1960-1962$ & 17 & 10 & $0 \cdot 63$ \\
$1963-1965$ & 12 & 10 & $0 \cdot 55$ \\
$1966-1968$ & 13 & 9 & $0 \cdot 60$ \\
$1969-1971$ & 21 & 5 & $0 \cdot 81$ \\
\hline
\end{tabular}

of isolated cases increased, there was no reduction in the incidence rate. Instead there was a slight increase. This may mean that some isolated cases born in the earlier periods have not been ascertained. Alternatively, this observation could be an expression of random variation attributable to the small numbers involved.

Given the high overall proportion of isolated cases found, it is unlikely that this survey missed many such cases. However, even if as many as a dozen cases have not been included here, the resulting incidence rate $\left(20.9 \times 10^{-5}\right)$ would still be lower than the recent studies cited above.

Although there has been an increase in the proportion of isolated cases in the period 1969 to 1971 and some reduction in the number of preventable cases, there has been no significant decrease in the incidence rate. This is despite the availability for over a decade of an active programme of genetic counselling based on carrier detection studies in New South Wales and the Australian Capital Territory.

As shown in table 2 , only $14 \%(14 / 99)$ of the cases ascertained here could be regarded as having been avoidable by genetic counselling in the present circumstances. Even if none of the 'theoretically preventable' cases had been born, the incidence of Duchenne muscular dystrophy between 1960 and 1971 would still have been $16.0 \times 10^{-5}$. These results indicate that a programme of genetic counselling alone is insufficient to lower the incidence significantly in the population. Nevertheless, the availability of carrier detection tests and the associated counselling for female relatives is of the greatest importance to these women in preventing any further occurrence of Duchenne muscular dystrophy in their families.

\section{References}

1 Gardner-Medwin D. Mutation rate in Duchenne type of muscular dystrophy. J Med Genet 1970;7:334-7.

2 Kakulas BA, Hurse PV. The muscular dystrophies: I results of carrier detection and genetic counselling in Western Australia. Records of the Adelaide Children's Hospital 1977;1 :232-43.

3 Lawrence EF, Brown B, Hopkins IJ. Pseudohypertrophic muscular dystrophy of childhood: an epidemiological survey in Victoria. Aust $N Z J$ Med 1973;3:142-51.

4 Adkins G, Birchley N, Bourne P. Pseudohypertrophic muscular dystrophy of childhood in Queensland. University of Queensland: Department of Social and Preventive 0 Medicine, 1978:1446.

5 Becker, PE, Lenz F. Zur Schätzung der Mutationsrate $\mathscr{O}$ der Muskeldystrophien. Z Menschl Vererb Konstit Lehre $1955 ; 33: 42-56$.

6 Becker PE, Lenz F. Zur Schätzung der Mutationsrate der Muskeldystrophien: Nachtrag. $Z$ Menschl Vererb Konstit Lehre 1956;33:463-4. 
7 Stephens FE, Tyler FH. Studies in disorders of muscles. V. The inheritance of childhood progressive muscular dystrophy in 33 kindreds. Am J Hum Genet $1951 ; 3: 111-25$.

${ }^{8}$ Blyth H, Pugh RJ. Muscular dystrophy in childhood. The genetic aspect. Ann Hum Genet 1959;23:127-63.

9 Moser H, Wiesmann U, Richterich R, Rossi E. Progressive Muskeldystrophien. VI. Häufigkeit, Klinik und Genetik der Duchenne-form. Schweiz Med Wochenschr 1964;94:1610-21.

10 Walton JN. On the inheritance of muscular dystrophy. Ann Hum Genet $1955 ; 20: 1-38$.

11 Stevenson AC. Muscular dystrophy in Northern Ireland. I. An account of condition of fifty-one families. Ann Eugen 1953;18:50-93.

12 Stevenson AC. Muscular dystrophy in Northern Ireland. IV. Some additional data. Ann Hum Genet 1958;22;231-4.

13 Kuroiwa Y, Miyazaki T. Epidemiological study of myopathy in Japan. In: Milhorat T, ed. Exploratory concepts in muscular dystrophy and related disorders. Amsterdam: Excerpta Medica, 1967:98-102.
14 Prot J. Genetic-epidemiological studies in progressive muscular dystrophy.J Med Genet 1971 ;8:90-6.

15 Brooks AP, Emery AEH. The incidence of Duchenne muscular dystrophy in the South East of Scotland. Clin Genet 1977;11:290-4.

16 Danieli GA, Mostacciuolo ML, Bonfante A, Angelini C. Duchenne muscular dystrophy. A population study. Hum Genet 1977;35: 223-31.

17 Australian Bureau of Statistics. Handbook of local statistics, New South Wales. Catalogue No 1304.1,1978.

18 Cheeseman EA, Kilpatrick SJ, Stevenson AC, Smith CAB. The sex ratio of mutation rates of sex-linked recessive genes in man with particular reference to Duchenne muscular dystrophy. Ann Hum Genet 1958; 22:235-43.

Requests for reprints to Dr A E Stark, School of Community Medicine, University of New South Wales, PO Box 1, Kensington, NSW 2033, Australia. 